\title{
Potentiality of Selected Commercial Antibiotics Challenged with Aeromonas sp.
}

\author{
Sharif Neowajh, Md. Mer Mosharraf Hossain*, Ibrahim Kholil , Sumana Nasrin Mona, \\ Sherajul Islam, Mitheela Kabi
}

\begin{abstract}
Department of Fisheries and Marine Bioscience, Faculty of Biological Science \& Technology, Jessore University of Science and Technology, Bangladesh
\end{abstract}

Copyright (C) 2015 Horizon Research Publishing All rights reserved.

\begin{abstract}
This study was intended to address, the effect of oxytetracycline, erythromycin, and streptomycin on the antimicrobial resistance of Aeromonas sp. isolated during the production process, from infected common carp (Cyprinous carpio). Antimicrobial resistance patterns were defined by determination of minimal inhibitory concentrations (MIC) of three antimicrobial drugs, and bacteria. Results indicated that In vitro bactericidal activity, oxytetracycline showed lowest number of bacterial colonies $\left(1 \times 10^{-4}\right.$ c.f.u. $\left./ \mathrm{ml}\right)$ than erythromycin $\left(3 \times 10^{-4}\right)$ and streptomycin $\left(4.5 \times 10^{-4}\right)$ compared to the control $\left(9 \times 10^{-4}\right)$. Oxytetracycline showed the highest maximum zone of inhibition $(20 \mathrm{~mm})$ than erythromycin $(18 \mathrm{~mm})$ and streptomycin $(15 \mathrm{~mm})$ in antibiotic susceptibility test. In infection inhibition assay, serum from oxytetracycline fed diets inhibited Aeromonas infection to common carp. The susceptibility of the fish fed antibiotics (50 $\mathrm{g} / \mathrm{mg}$ feed) and challenge with Aeromonas sp. $\left(1 \times 10^{-4}\right)$ was examined for 30 days. There was high relative percent of survivility (RPS) in oxytetracycline was $73 \%$. Very low RPS $63 \%$ and $47.37 \%$ was found in erythromycin and streptomycin against Aeromonas sp. infection. These results demonstrated that the oxytetracycline might be a potential for Aeromonas sp. infection to common carp (Cyprinous carpio).
\end{abstract}

Keywords Aeromonas sp. Potentiality, Antibiotics, Antimicrobial Resistance, Minimal Inhibitory Concentrations (MIC) and Disease Resistance

\section{Introduction}

Fish production through aquaculture is increasing day by day. But the total production is still behind the demand. Disease is one of the major limiting factors to obtain the production target. Among various diseases bacterial disease in fish is a serious threat to aquaculture system in Bangladesh. Various types of disease such as ulcer type disease including epizootic ulcerative syndrome, bacterial hemorrhagic septicemia, tail and fin rot, bacterial gill rot, dropsy, columnaris disease, fungal disease and parasitic disease are important limiting factors for sustainable fish production [1]. Infections caused by motile aeromonads are probably the most common bacterial disease of freshwater fish [2]. Resistance of Aeromonas sp. to commonly used antibiotics is an emerging problem in the farmed fish. Therefore, the present work attempted to evaluate the potentiality of antibiotics to inhibition assay, bactericidal activity and susceptibility against Aeromonas sp. infection.

\section{Materials and Methods}

\subsection{Fish and Management}

Common carp, Cyprinous carpio (weight $270.7 \pm 10.4 \mathrm{~g}$, $\mathrm{N}=100$ ) was obtained from fish farm located at Chachra, Jessore and were transported to the laboratory of Fisheries and Marine Bioscience (FMB), Jessore University of Science and Technology (JUST), on July to December 2013. The fish were immediately examined by their movement, eye condition and external lesion to find out their health status and acclimatized in the indoor aquarium $(100 \mathrm{~L})$ with recirculating aerated water. Continuous aeration was provided to maintain dissolved oxygen level at $7.5 \pm 0.5$ $\mathrm{mgl}^{-1}$ and one-third of the aquarium water was exchanged daily and by siphoning the waste materials was removed. During the experimental period water temperature, $\mathrm{pH}$ and TDS (total dissolved solid) were $22 \pm 0.8^{\circ} \mathrm{C}, 5.94 \pm 0.21$ and $434 \pm 0.29 \mathrm{mgl}^{-1}$ respectively. Fishes were provided with normal feed (without herbal extract) at the rate of $5 \%$ of their body weight twice a day at 09:00 and 16:00 h for 3 days but at the first day of their arrival no feed was provided.

\subsection{Aeromonas Hydrophila Isolation}

A. hydrophila isolated from diseased common carp (Cyprinous carpio), was used in FMB laboratory for the study. Stocks were grown in brain heart infusion (BHI, 
Hi-media, Indian) and nutrient broth for $24 \mathrm{hrs}$ at $37^{\circ} \mathrm{C}$ and then kept in $-20^{\circ} \mathrm{C}$ until use. The subculture was taken and centrifuged (4000 rpm for $15 \mathrm{~min}$ ), after centrifugation the supernatant was discarded and the pellet was resuspended in sterile phosphate buffer saline (PBS). The culture was adjusted at $3.5 \times 10^{-7}$ colony forming units (CFU) $\mathrm{ml}^{-1}$ by 10 time's serial dilution and incubated at $37^{\circ} \mathrm{C}$ for 24 hours. The bacterium was confirmed by some biochemical test (Table 1).

Table 1. Identifying characteristics of fish pathogenic strain Aeromonas hydrophila

\begin{tabular}{|c|c|}
\hline Identifying characteristics & Aeromonas hydrophila \\
\hline Colony & Yellowish \\
\hline Morphology & Small rods \\
\hline Gram strain & - \\
\hline Catalase & + \\
\hline Oxidase & + \\
\hline Gelatin liquefaction & + \\
\hline Indole production & + \\
\hline OF test & $\mathrm{F}$ \\
\hline Arabinose & + \\
\hline Manitol & + \\
\hline Sucrose & + \\
\hline Inositol & + \\
\hline Esculin hydrolysis & + \\
\hline Voges-proskauer reaction & + \\
\hline Ammonium production & - \\
\hline Glucose & G \\
\hline
\end{tabular}

Note: $+=$ positive reaction; $-=$ negative reaction; $\mathrm{O}=$ oxidation; $\mathrm{F}=$ fermentation; $\mathrm{G}=$ gas.

\subsection{Antibiotic Treatment Conditions}

The study was carried out during a disease outbreak (caused by the bacteria Aeromonas hydrophila) occurring in a common carp, Cyprinous carpio lot. The fish were treated on decision of the veterinarian with antibiotics at $12 \mathrm{mg}$ per $\mathrm{kg}$ of bodyweight per day during eight consecutive days. The trout were fed the antibiotics-supplemented food at a rate of $0.5 \%$ of body weight per day. At the onset of treatment, mean fish weight was approximately $270 \mathrm{~g}$ and water temperature was about $30^{\circ} \mathrm{C}$. This treatment was successful in curing the affected common carp lot. At the end of the study period, water temperature in the farm environment was about $25-30{ }^{\circ} \mathrm{C}$.

\subsection{Bleeding, Serum Separation and Bactericidal Activity Test}

Blood from the randomly selected fish were drawn directly from the caudal vein with the help of a sterilized 1 $\mathrm{ml}$ hypodermal syringe containing EDTA (Ethylene-Diamine-Tetra-Acetic Acid) as an anticoagulant using 24 gauge needles. For serum separation blood was collected without anticoagulant in serological tubes and stored in a refrigerator overnight. The clot was then spun down at $4500 \mathrm{~g}$ for $10 \mathrm{~min}$. The collected serum was stored in sterile serum tubes at $-20{ }^{\circ} \mathrm{C}$ until used for assays. All the procedures were carried out in the sterilized condition. $A$. hydrophila was used as a model to examine the effectiveness of antibiotics to kill the bacterial infection. $100 \mu \mathrm{l}$ of serum was added to $100 \mu \mathrm{l}$ bacterial suspension and mixed before incubated for 1 hours at $37^{\circ} \mathrm{C}$. A blank control was prepared by replacing serum with sterile PBS. The mixture was then diluted with sterile $0.05 \mathrm{M}$ sodium phosphate buffer, PBS $(\mathrm{pH} 6.2)$ at a ratio of 1:10. The serum-bacterial mixture (100 $\mu 1)$ was plated onto the nutrient agar plates with incubation for 24 hours at $37^{0} \mathrm{C}$ before the number of colonies was counted.

\subsection{Antibiotic Susceptibility Test}

Antibiotic susceptibility tests were carried out against $A$. hydrophila with three antibiotics by disc diffusion method [3]. Antibiotics disc of oxytetacyclene $(30 \mu \mathrm{g})$, erithromycine $(30 \mu \mathrm{g})$ and streptomycin $(30 \mu \mathrm{g})$ were used for the study [4]. $\mathrm{NA}$ and $\mathrm{BHI}$ agar was poured into the plates and allowed to solidify. The standard inoculum $\left(10^{6} \mathrm{cfu} / \mathrm{ml}\right)$ was swabbed over the surface of the media using sterile cotton swab to ensure the confluent growth. The plates with incubation for 24 hours at $37^{\circ} \mathrm{C}$ before the number of colonies were counted. All the experiments were carried out in triplicate.

\subsection{Agglutination Titer Assay}

The test for agglutination titer was realized individually for bacterium Aeromonas sp. according to Yildirim, et al. 2003 [5]. The bacterial cell suspension was centrifuged at $300 \times \mathrm{g}$ for $15 \mathrm{~min}$ and supernatant was discarded. The resulting pellets were washed twice with $0.85 \%$ phosphate buffer saline (PBS) solution and pellets were resunpended in PBS to an optical density of 0.8 at $540 \mathrm{~nm}$. Starting with a dilution of 1:10 (10- $\mu 1$ serum and $90 \mu \mathrm{l}$ PBS), two-fold serial serum dilutions were made in 96-well round bottom microtiter plates by adding $50 \mu$ of diluted serum into the reaming wells plated with $50 \mu \mathrm{l}$ of PBS. Thereafter, $50 \mu \mathrm{l}$ of bacterial cell suspension was added to each well; thus, the initial serum dilution was 1:20. The plates were covered with plastic film and incubated at room temperature for 2 hours at $4^{0} \mathrm{C}$ for 24 hours. The agglutination end point was estimated as the last serum dilution where cell agglutination was visible after incubation. Agglutination titers were reported as $\log _{10}$ of the reciprocal of the highest serum dilution showing visible agglutination as compared to the positive control.

\subsection{Assessment of Aeromonas infection inhibition}

Aeromonas infection inhibition assay was carried out as follows: Aeromonas cells were grown in 96-well plates at $37^{\circ} \mathrm{C}$ until the density reached to $1 \times 10^{6} \mathrm{cfu} / \mathrm{ml}$. The cells were washed gently with PBS and then incubated for 4 hours 
at $37^{\circ} \mathrm{C}$ with $100 \mu \mathrm{l}$ serum from oxytetracycline fed diets against the target bacterium diluted at 1:50, 1:100 or 1:200 with maintenance medium. After incubation, the cells were washed twice with PBS and then infected with Aeromonas sp. at $\mathrm{LD}_{50}$ at $37^{\circ} \mathrm{C}$ for 1 hour. After bacterial adsorption, the unattached bacteria were removed by washing with PBS and $100 \mu \mathrm{l}$ maintenance media were added. The infection was allowed for 5 days at $37^{\circ} \mathrm{C}$ and the cytopathic effect (CPE) was monitored by photography microscope, serum (1:50 diluted) was used as negative control. The experiment was performed twice in duplicate.

\subsection{Challenge Test}

To evaluate the effects of antibiotics in the diet on fish disease resistance, Aeromonas sp. was used as the pathogenic agent. The susceptibility of the fish fed with different antibiotics and challenged with Aeromonas sp. $\left(1 \times 10^{-4}\right.$ c.f.u. $\left./ \mathrm{ml}\right)$ was examined for 30 days. The relative percent survival (RPS) was calculated by following formula [6]:

$$
R P S=1-\left(\frac{\text { percent mortality in treated group }}{\text { percent mortality in control group }}\right) \times 100
$$

\subsection{Statistical Analysis}

All the data are expressed as mean \pm SE. Statistical analysis of data involved one way analysis of variance (ANOVA) followed by the comparison of means following Stat Professional Software and SPSS windows 15.0 version. The level of significance was expressed as p-value at 0.05 levels.

\section{Results}

\subsection{Bactericidal Activity}

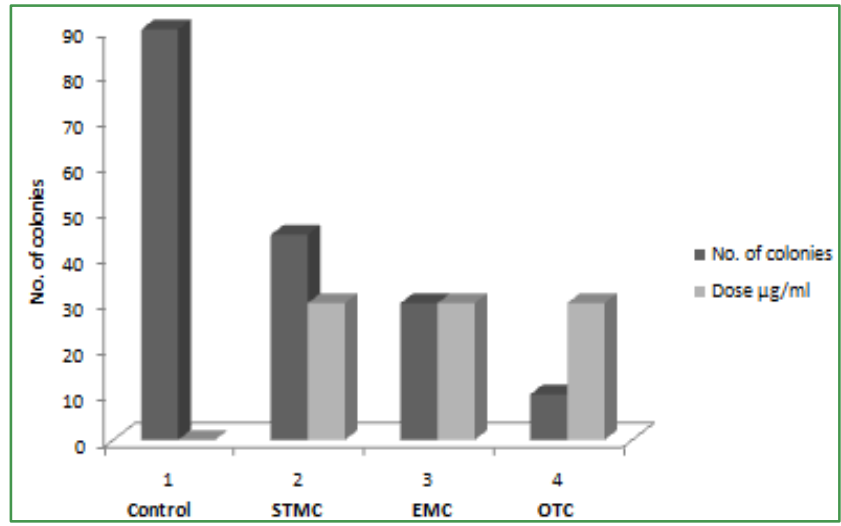

Figure 1. Bactericidal activity of serum of common carp, Cyprinous carpio fed with different doses of antibiotics supplemented diets against Aeromonas sp.

The lowest number of bacterial colonies indicated the efficiency of antibiotics to kill the pathogen. With oxytetracycline the lowest number of colonies i.e. $1 \times 10^{-4}$ on media with the $30 \mu \mathrm{g} / \mathrm{ml}$ dose with highly significant differences to the control, $9 \times 10^{-4}$. The $30 \mu \mathrm{g} / \mathrm{ml}$ dose recorded a highest number of colonies; $3 \times 10^{-4}$ and $4.5 \times 10^{-4}$ for erythromycin and streptomycin respectively in Figure 1.

\subsection{Antibiotic Susceptibility Test}

In the drug susceptibility assays, Aeromonas sp. was susceptible against oxytetracycline $(20 \mathrm{~mm})$, erythromycin $(18 \mathrm{~mm})$ and streptomycin $(15 \mathrm{~mm})$. In the antibiotic susceptibility test, oxytetracycline exhibited maximum activity than that of erythromycin and streptomycin in Figure 2.

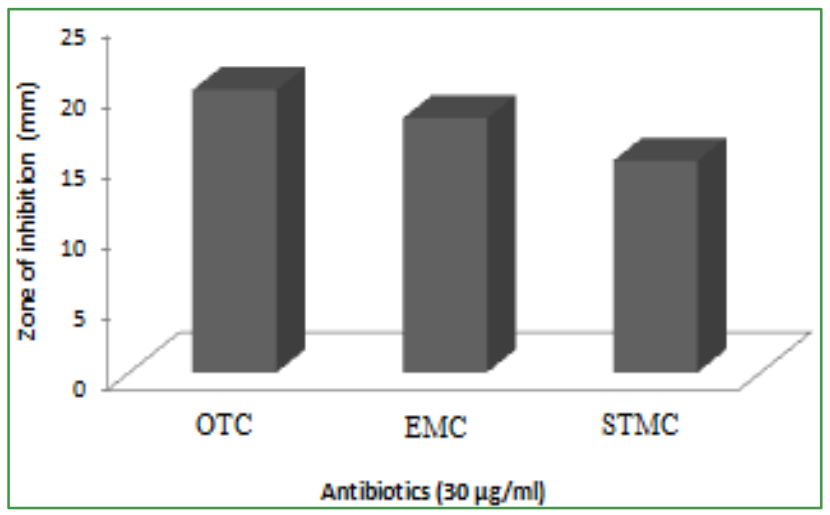

Figure 2. Antibiotic susceptibility test showed zone of inhibition of some antibiotics against Aeromonas sp.

\subsection{Bacterial Agglutination Test}

The agglutination antibody titers were quantified following the standard micro-agglutination procedure using serial two fold dilution of each antibiotic pool. Using highest antibiotic dilution showed visible agglutination as compared to the positive control. Negative agglutinations were found usually lowest antibiotic dilution.

\subsection{Infection Inhibition Assay}

Table 3. Aeromonas sp. infection inhibition assay using fish antiserum in vitro.

\begin{tabular}{|c|c|c|c|c|c|c|}
\hline Serum & $\begin{array}{c}\text { Sera } \\
\text { dilution }\end{array}$ & \multicolumn{5}{|c|}{ Days post infection } \\
\hline & & $\begin{array}{c}1 \\
\text { day }\end{array}$ & $\begin{array}{c}2^{\text {nd }} \\
\text { day }\end{array}$ & $\begin{array}{c}3^{\text {rd }} \\
\text { day }\end{array}$ & $\begin{array}{c}4^{\text {th }} \\
\text { day }\end{array}$ & $\begin{array}{c}5^{\text {th }} \\
\text { day }\end{array}$ \\
\hline Pre-serum & $1: 50$ & - & + & ++ & +++ & +++ \\
\hline & $1: 50$ & - & - & - & - & + \\
\hline Post-serum & $1: 100$ & - & - & - & + & ++ \\
\hline & $1: 200$ & - & - & + & ++ & +++ \\
\hline & & & & & & \\
\hline
\end{tabular}

Note:,$+++ 50 \%-75 \%$ cells showing CPE;,$++ 25 \%-50 \%$ cells showing $\mathrm{CPE} ;+$, few cells showing CPE; -, No CPE.

To determine the role of bacterium during Aeromonas sp. at $\mathrm{LD}_{50}$ infection, serum against the molecule were tested for the ability of inhibiting Aeromonas sp. infection. While Aeromonas sp. cells were incubated with serum and infected 
with Aeromonas sp., less than $25 \%$ of cells showed obvious $\mathrm{CPE}$ at the second day after infection, and more than 50\% CPE occurred at the fifth day (Table 3). By contrast, the CPE didn't appear until the fifth day in the presence of 1:50 diluted post-immune sera, but the CPE was gradually aggravated by pre-incubation with lower concentrations of post-immune sera at 1:100 or 1:200 dilutions (Table 3).

\subsection{Challenge Test}

The highest survivility was $75 \%$ and $65 \%$ in fish fed with $50 \mu \mathrm{g} / \mathrm{mg}$ of oxytetracycline and erythromycin for 30 days against Aeromonas sp. The lowest survivility of 5\% was observed in fish fed with $0 \%$ dose diet. The survivility decreased to $50 \%$ with $50 \mu \mathrm{g} / \mathrm{mg}$ of streptomycin dose diet (Fig. 3). The lowest survivility of $5 \%$ was noted in the control while $50 \%$ survivility was observed for streptomycin $50 \mu \mathrm{g} / \mathrm{mg}$ dose applications (Fig. 3). The highest RPS; 73\% was found for oxytetracycline, $63 \%$ and $47.37 \%$ for erythromycin and streptomycin respectively.

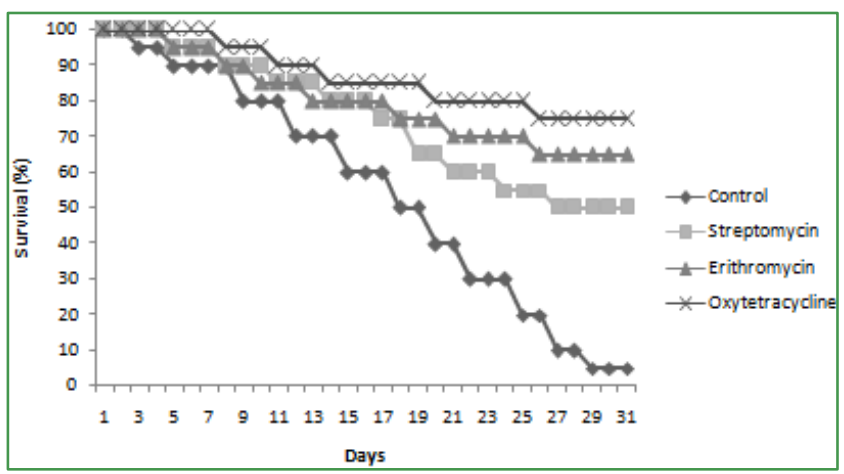

Figure 3. The survivability of common carp fed with different doses of antibiotic supplemented diets against Aeromonas sp.

\section{Discussion}

The motile Aeromonas group is responsible for severe fish diseases, such as hemorrhagic septicemia $[7,8,9]$ and ulcerative disease of fish [10]. The worldwide distribution of this group is a consequence of its great adaptability to different aquatic environments [11]. Infections by Aeromonas had been observed in various freshwater fish species and eventually in marine fish, reptile, bovine, and man [7,12]. MIC has been recorded for several Aeromonas hydrophila strains around the world [13,14,]. In the present study Aeromonas sp. was isolated from hemorrhagic septicemia and ulcerative disease affected common carp.

In the present study, Studied on pure cultures of Aeromonas sp. were isolated from the skin, kidney, heart, and liver of the common carp. The isolates were found to be sensitive to and oxytetracycline, erythromycin and streptomycin. Oxytetracycline showed the better result than the erythromycin and streptomycin. Pure cultures of Aeromonas hydrophila were isolated from the skin, kidney, heart, and liver of the gold fish. All of the isolates were found to be susceptible to oxytetracycline, neomycin, streptomycin and resistant to ampicilin, amphotericin, bacitrain, cephalexin and moderately sensitive to Erythromycin, Kanamycin, [15] which support the present study. The isolates of Aeromonas hydrophilia were tested for their susceptibility to florephenikol, flumequine, rithromycin olaqindox and oxitetracycline [16], which support the present study. Antibiotic susceptibility assay with commercial antibiotics and oxytetracycline showed the better result than erythromycin and streptomycin [4], which supports the present study.

In the present study bacterial agglutination was performed and oxytetracycline showed the better result than the erythromycin and streptomycin at the same dose in 96 wells plate. In the present study assessment of MIC was also performed and result showed that, $50 \mu \mathrm{g} / \mathrm{ml}$ for oxytetracycline and $55 \mu \mathrm{g} / \mathrm{ml}, 60 \mu \mathrm{g} / \mathrm{ml}$ for erythromycin and streptomycin respectively. Miranda and Zemelman, (2002) studied on bacterial resistance to oxytetracycline in Chilean salmon farming by spread plate method and agar plate dilution method. They recommended that 30 to 100 $\mu \mathrm{g} / \mathrm{ml}$ oxytetracycline is helpful for bacterial inhabitation [17], which supports the present study. Singh et al., (2009) isolated twelve isolates of oxytetracycline resistant bacteria were mainly dominated in adult fishes. Their selected strains exhibited high levels of oxytetracycline resistance with minimum inhibitory concentrations (MICs) ranging from 50 to $600 \mu \mathrm{g} / \mathrm{ml}$ [18], which also support the present study. Guz and Kozinska, (2004), isolated twenty one Aeromonas pathogen from carp (Cyprinus carpio) and tested susceptibility to 22 antimicrobial agents by disc division method. They resulted that, $100 \%$ were resistant to ampicillin and penicillin, and sensitive to trimethoprim-sulphamides, oxolinic acid, flumequine, chloramphenicol, norfloxacin, linkomycin, pefloxacin. Most isolates were resistant to cephalothin (57\%) and erythromycin (52\%) [19].

Haque et al., (2014) observed the effectiveness of antibiotic, oxytetracycline reducing the bacterial load in rohu fish under artificial culture condition in the laboratory. They used live fish method for experiment and resulted that $2 \mathrm{gm} / \mathrm{kg}$ oxytetracycline in diet, twice daily is potential antibiotic to reduce bacterial load in fish and can be used commercially for maintaining the fish health in aquarium condition [20], dose did not support the present study because fishes may be treated prior to study time and bacteria gained resistancy against minimum dose or dose may be varied species to species. In the present study challenge test was performed with oxytetracycline, erythromycin, streptomycin and control against Aeromnas sp. affected fish. Oxytetracycline treated fish showed highest RPS value than the other two antibiotics and resulted that antibiotics have the potentiality to cure the fishes, which support various workers in this field.

Aeromonas sp. is very common bacterial pathogen which affects fish species frequently and can cause severe disease. At the end of present study it can be concluded that, Aeromonas sp. was responsible for hemorrhagic septicemia and ulcerative disease of fish. The Aeromonas sp. was found to be sensitive to oxytetracycline, erythromycin and streptomycin. 


\section{Conclusions}

In vitro bactericidal activity, oxytetracycline showed lowest number of bacterial colonies $\left(1 \times 10^{-4}\right.$ c.f.u. $\left./ \mathrm{ml}\right)$ and highest maximum zone of inhibition $(20 \mathrm{~mm})$ in antibiotic susceptibility test. In infection inhibition assay, serum from oxytetracycline fed diets inhibited Aeromonas infection to common carp, which suggested that the serum from oxytetracycline fed diets played an important role in the infection of Aeromonas sp. to common carps. There was high relative percent of survivility (RPS); $73 \%$ in oxytetracycline against Aeromonas sp. infection, so the oxytetracycline than other antibiotic tested in this study might be a potential for Aeromonas sp. infection to common carp (Cyprinous carpio).

\section{REFERENCES}

[1] Chowdhury, M.B.R., 1997. Bacterial involvement in fish disease in Bangladesh. Presented at the International Symposium on Disease in Aquaculture, October 3-6. Hirosima, Japan. Abstract III-2: 24.

[2] Kadlec, K., Czapiewski, V. E., Kaspar, H., Wallmann, J., Michael, G.B., 2011. Molecular basis of sulfonamide and trimethoprim resistance in fish-pathogenic Aeromonas isolates. Applied Environmental Microbiology, 77: 7147-7150.

[3] Cappuccino, G., Sherman, N., 1998. Microbiology: a laboratory manual. Benjamin/Cumming Science Publishing, California, 254

[4] Dhayanithi, N.B., Kumar, A.T.T., Balasubramanian, T., 2012. Effect of agallocha leaves against Aeromonas hydrophila in marine ornamental fish, Amphiprion sebae. Indian Journal of Geo-Marine Sciences, 41(1): 76-82.

[5] Yildirim, M., Lim, C., Wan, P., Klesius, P.H., 2003. Growth performance and immune response of channel catfish (Ictalurus punctatus) fed diets containing graded levels of gossypol-acetic acid. Aquaculture, 219: 751-768.

[6] Amend, D.F., 1981. Potentiality testing of fish vaccines. Developments in Biological standardization, 49: 447-454.

[7] Bullock, G.L., Conroy, D.A., Sniesko, S.F., 1971. Septicemic diseases caused by motile aeromonads and pseudomonads. In: Sniesko S.F. Axelrod H.R. (Ed.) Diseases of fishes. Neptune: T.F.H. Publications, 2: 21-41.

[8] Egusa, S., 1974. Infectious diseases of fish. Tokyo: Kouseisha Kouseikaku, 554.

[9] Schaperclaus, W., Kulov, H., Schreckebach K., 1992. Infectious abdominal dropsy. In: Schaperclaus W. (Ed.). Fish diseases. Berlin: Akademie Verlag, 1: 401-458.

[10] Karunasagar, I., Sugumar, G., Karunasagar, I., 1995. Virulence characters of Aeromonas sp. isolated from EUS-affected fish. In: Sharif, M.; Arthur, J.R.; Subasinghe, R.P. (Ed.). Diseases in Asian aquaculture II. Manila: Asian Fisheries Society, Fish Health Section, 307-314.

[11] Mateos, D., Anguita, J., Naharro, G., Paniagua, C., 1993. Influence of growth temperature on the production of extracellular virulence factors and pathogenicity of environmental and human strains of Aeromonas hydrophila. Journal of Applied Bacteriology, 74: 111-118.

[12] Khardori, N., Fainstein, V., 1988. Aeromonas and Plesiomonas as etiological agents. Annual Review of Microbiology, 42: 395- 419.

[13] Pettibone, G.W., Mear, J.P., Sampsell, B.M., 1996. Incidence of antibiotic and metal resistance and plasmid carriage in Aeromonas isolated from brown nullhead (Ictalurus nebulosus). Letters in Applied Microbiology, 23: 234-240.

[14] Son, R., Rusul, G., Sahilah, A.M., Zainuri, A., Raha, A.R., Salmah, I., 1997. Antibiotic resistance and plasmid profile of Aeromonas hydrophila isolates from cultured fish, Telapia (Telapia mossambica). Letters in Applied Microbiology, 24: 479-482.

[15] Jeeva, S., Lekshmi,P.N.C.J., Brindha, J.R., Vasudevan, A., 2013. Studies on antibiotic subsceptibility of Aeromonas hydrophila Isolated from gold fish (Carassius auratus). International Journal of Current Microbiology and applied Science, 2(12): 7-13.

[16] Stojanov, I., Plavsa, N., Stojanovic, D., Ratajac, R., Radulovic, J.P., Pusic, I., Kapetanov, M., 2010. Susceptibility of Aeromonous hydrophila isolates to antimicrobial drug Lucrări Ştiințifice Medicina veterinara, 43 (1): 132.

[17] Miranda, C.D., Zemelman, R., 2002. Bacterial resistance to oxytetracycline in Chilean salmon farming. Aquaculture, 212: $31-47$.

[18] Singh, A.K., Rathore, G., Singh, V., Mani, I., Singh, R.K., Mishra, S.K., Mishra, B.N., Verma, O.P., 2009. Bacterial resistance to oxytetracycline in different life stages of Indian freshwater carp aquaculture system. International Journal of Microbiology Research, 1(1): 25-34.

[19] Guz, L., Kozinska, A., 2004. Antibiotic susceptibility of Aeromonous hydrophila and aeromonous sobria isolated from farmed carp (Cyprinus carpio). Veterinary Institute of Pulawy, 48: 391-395.

[20] Haque, S.A., Reza, M.S., Sharker, M.R., Rahman, M.M., Islam M.A., 2014. Effectiveness of oxytetracycline in reducing the bacterial load in rohu fish (Labeo rohita) under laboratory culture condition. Journal of Coastal Life Medicine, 2(4): 259-263 